\title{
An Analysis of English Speaking Syllable Words Stress Errors by The Students of English Education Study Program of University of Bengkulu
}

\author{
Ronaldi Styvant \\ English Education Study Program, Department of Language and Art \\ University of Bengkulu \\ ronaldystyvant@gmail.com \\ Arasuli \\ English Education Study Program, Department of Language and Art \\ University of Bengkulu \\ arasuli.msi@gmail.com \\ Rudi Afriazi \\ English Education Study Program, Department of Language and Art \\ University of Bengkulu \\ Rudiafriazi88@gmail.com
}

\begin{abstract}
ABSTRAK
Penelitian ini bertujuan untuk menemukan pola penekanan suku Bahasa Inggris oleh mahasiswa Bahasa Inggris, Universitas Bengkulu. Subjek dari penelitian ini adalah 19 mahasiswa program Bahasa Inggris yang memiliki nilai IPK tertingi dan nilai speaking dan phonetic phonology tertinggi ataupun kedua-duanya. Metode pengumpulan data adalah merekam. Data diambil dengan cara merekam pengucapan mereka ketika mengucapkan kata dengan penekanan dan program Audacity untuk menganalisa data. Hasil dari penelitian ini menunjukan bahwa nilai mhasiswa dalam penyebutan penekanan kata di awal suku kata dan penekanan kata di suku kata kedua yaitu sedang dan 2 penekanan dalam 1 kata yaitu rendah. Sementara itu penelitian ini juga menemukan bahwa kebanyakan murid lebih cenderung untuk meletakkan penekanan suku kata di suku kata awal.

Kata Kunci: Analisis, Kata, tekanan, kesalahan, Suku Kata, Mahasiswa
\end{abstract}

\begin{abstract}
This research was aimed at finding out the errors of English speaking syllable stress by the students of English Education Study Program, University of Bengkulu. The subject of this study was 19 students with highest GPA and speaking and Phonetic phonology score or both of them of English Program. The method of data collection was recorded. The data were collected by recording their pronunciation in reading words stress and Audacity program to analysze the data. The result of this research showed that English Students pronunced syllable words stress in the first syllable and second syllable with average predicate and 2 stresses in a word with low predicate. Meanwhile, this research also found that a lot of students put the stress on the first syllable.
\end{abstract}

Key words: Analysis, Word, Stress, Error, Syllable word, Students 


\section{Introduction}

Word stress or lexical stress is the stress place on syllables within words. According to Bowen (2000) There are some rule in English stress syllable. There are some on the first syllable; some are on the penultimate syllable, stress on the ante-penultimate syllable and the last is stress in compound and the last is stress in compound word. Bear (2015) in Sabarudin (2016) explains that words consist of syllable and the sllable itself is a unit of sound which includes a vowel sound. In the word 'information' there are four syllable but the stress is placed on the penultimate syllable, ' in -for -MAtion".

When talking about stress is also talking about syllable and sentence stress. According to Fudge (2015) there are two kinds of stress, they are sentence-stress and syllable stress. Sentence stress is the manner in which stress is distribute on the word and syllable stress is the manner in which stress is distributed on the syllable. and he stated there is a sign (") to put stress placement in a word.

A stressed syllable is produced by pushing more air out of the lungs inone syllable relative to others. A stressed syllable thus has greater respiratory energy than neighboring unstressed syllables. It may also have an increase in laryngeal activity. Stress can always be defined in terms of something a speaker does in one part of an utterance relative to another (Ladefoged, 1982: 104).

According to Cruttenten (2008), the term 'stress' refers to 'accent and prominance ' which agree that loudness in accented syllable is produced by greater breath effort and muscular energy of vocal fold. Thus, the sound of the syllable produced is louder than others syllable. At a word level, there is always a syllable which is more prominent syllable than the others. Verb, adjective, and noun are the usually stressed. The stressed rarely fals on gramatical words such as on, of , this, that, the, and more .but it does not mean they could not be stressed. Those grammatical words could be stressed to make a special attention to it or to emphasize it. 
The researcher thought that why this research need to be examine because as we know that stress can influence the meaning of the language and almost all of Indonesian words or language not using stress except some tradional language in Indonesia, for example Padang, Medan, Sunda, and etc. So the researcher need to know how about student of English Education Study Program at Bengkulu University pronounce English syllable words stress it self .

There are some previous studies that related to this research, The first by Bian (2003) with the tittle "The Influence of Chinesse Stress on English Pronunciation Teaching and Learning " in this research the researcher examines the differencess between chinese and English stress.And also would like to investigate the reasons for chinesse EFL learners' pronunciation difficulties in English stress. the result of this research showed Chinese learners of English often misplace stress in an English word and sentences. The second by Toro-Soto, Rodríguez- Fornells, A., and Sebastián-Gallés, N. (2007) with the tittle "Stress Placement and Word Segmentation by Spanisih Speakers", in this research the researcher focused on Spanish speakers whose stres pattern would mark the penultimate syllable of words. The result of this research is show stress and syllable information may contribute differently to segmentation of speech in languages such as Spanish and English. The third by Veronica ( 2017 ) was about the syllable stress placement.In this research, the researcher focused on the knowledge of the students. The data were collected by using test of the isolated word.The result of the research found that the english students have a low knowledge of word stress. The fourth by Anggi Oktaviani (2017) was about the word stress pattern by the students of English Education University of Bengkulu. The result of the study found there seems to be other patterns of the stress spoken by the subject such as multi stressed (MS) and no stress (NS).

From previous studies above, most of them focused on the stress placement by spoken or we can say they focused on skill, but in this research the researcher focused on how they speak English syllable words 
stress by the student of English Education Study Program, University of Bengkulu with different data collecting method.

This research had one research question, that is "What are the pronunciation errors of English Syllable words stress made by the fifth semester students of English Education Study Program at University of Bengkulu ?,The researcher hopes this research will give some influences to the student teachers, students and further researcher.

\section{Method}

This research is descriptive study as a research design. Parahoo (1997:142) describes a research design as "a plan that describes how, when and where data are to be collected and analysed" and according to Aggarawal (2008) descriptive research is related with gathering the information about prevailing conditions or situations for the purpose of description and interpretation.

The data of this study were analyzed by using both qualitative and quantitative method. Descriptive qualitative was used for analyzing and describing the result of the data. On the other hand, quantitative was used for calculating the data to get the percentage before describing it. This type of research method was not simply collecting and tabulating facts but included proper analyses, interpretation, comparisons, identification of trends and relationships.

The instrument in this research is recording. The researcher used Audacity to see the pattern of the data recorded in order to check the correct and incorrect of the students' pronunciation.

The subject of this research was the students with $25 \%$ of students from each class at English Education Study Program at University of Bengkulu with highest GPA or Speaking and Phonetic Phonology grades or both of them, where they are divided into two classes, which is 10 students by 40 in A class and 9 students by 38 students in B class.

Wolcott (1994) stated the term analysis is a generic term that embraces the three basis categories when analyzing data: description, analysis and interpretation. He suggests these categories are not exclusive; neither visibly separated by a line, yet identifying and distinguishing each 
one may be useful to organize and present the data. In qualitative data, especially content analysis, the data collection and gathering is simultaneously receiving some kind of interpretation. The reading of the data to follow the criteria to inclusion on the database, leads to initials interpretation and understanding of the concepts, and it depends on the researcher, the analysis can begin while collecting data (Marshall \& Rossman, 2006).

There are some procedures in the data analysis, they are : Making lists of English Syllable words, Recording English Students pronounciation about syllable words stres, Transcribing the data recorded based on Oxford Advanced Learner's Dictionary, Oxford University Press, Analyzing the data by comparing the transcription with receive pronunciation of English Syllable words to identify the wrong and right of the English Syllable words pronunciation with CO-researcher, Doing input the audio from native speaker and the data recorded by the students into Audacity, Then, comparing both of the data, The data would analyze based on the descriptive qualitative method.

\section{Result and Discussion}

Result

The main purpose of this research was expected to know how the students pronounced English syllable words stress and to identify to what extent were the errors of pronunciation of English syllable words stress made by the students of the English study program. The result of this research shows that most of English students pronounced the English syllable words stress incorrectly, specifically when they pronounced the word on 2 stresses in a word. The fact proved these 10 English words with 2 stresses in a word were pronounced incorrectly by more than $55 \%$ of the students. For example the English syllable words "Identification", most of the students pronounced it with "DEN" as primary stress but the truth is in the "CA", they pronounced it "accomoDATE" but the answer is "acCOModate", and etc.The data analysis recorded can be seen on the appendix 2. The researcher used Audacity in order to get data more valid 
to see the placement of the stress. Below is some of the examples of analysis by using Audacity for the word.

1. The percentage of students' pronunciation of English syllable words

\begin{tabular}{|ccc|}
\hline $\begin{array}{c}\text { Syllable of word } \\
\text { stress }\end{array}$ & Correct & Incorrect \\
\hline First syllable & $66 \%$ & $34 \%$ \\
\hline Second syllable & $53 \%$ & $47 \%$ \\
\hline 2 stresses in a word & $44 \%$ & $56 \%$ \\
\hline $\begin{array}{c}\text { total of persentages } \\
\text { syllable }\end{array}$ & $54 \%$ & $46 \%$ \\
\hline
\end{tabular}

Chart 1. shows the total of percentage English students that pronounced correctly start from first syllable words until 2 stresses in a word words

\section{Total of Percentages Syllable Stress}

\ Number of Percentages Correctly $⿴ 囗$ Number of Percentages Incorrectly

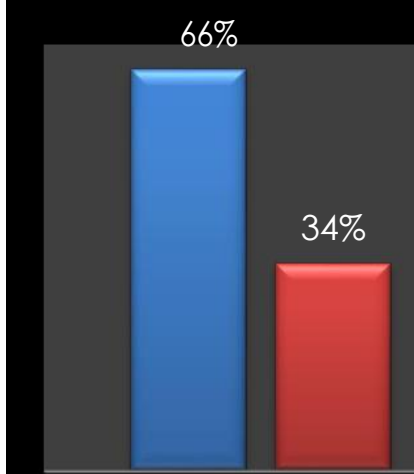

First syllable
$53 \%$

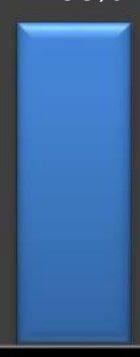

Second syllable
$56 \%$

$47 \%$ $44 \%$

the researcher found the arrangement is decreased there are $66 \%$, $53 \%$, and $44 \%$. Based on a classification score by Arikunto (2003), he divided classification score into four parts, they are low, average, good, and excellent. The students who achieve a score under 50 get low predicate, 50 - 69 average predicate, 70 - 79 get good predicate, and 80 - 100 get excellent predicate for their knowledge about English syllable stress. So the score for the student that pronounced English syllable words stress are average for first and second syllable words, low predicate for 2 stresses in a word. 


\section{Discussion}

Based on the Result, most of English students stressed words syllable with good pronunciation only with the words in the first and second syllable but As mentioned earlier, a word that have 2 stresses in a word got more than a half incorrect pronunciation by the student. By looking at the phenomena above, the researcher concluded some reason related to the problem.It happened because first, there is no stress used in Indonesian language and based on te result we know that the subject of the result make incorrect score for second syllable and 2 stresses in a word is increased beacuse the student often pronoun the word in the first syllable so they pronounced it in a wrong syllable and they did not familiar with the words that have 2 stresses in a word too. Stress does not influence meaning in Indonesian language such as English which has stress and the stress itself can change a meaning of word. Second, as Kozok (2011) stated that Indonesian stress was on the word not in the syllable. As the previous research by Veronica (2017) stated that mother tongue give effect to the language that we learn and there was not any stresses on the syllable of our native speaker.that is why the students were difficult to give a stress toward English word. Third, the students might prefer to use the feeling and sense instead of using the rule of English word stress. It also could be influenced by the context where the subject read the text so that they did not focus on the rule of word stress. They might think that the meaning is more important than the rule, because as long as people understand what they are saying, so the conversation and speech are made. On the other hand, Chyntia (2013) explain four important categories to be a professional teacher. The first category was the teacher must be able to pronounce English correctly. The second category was the teacher must have the abilty to speak English correctly. The third category was the teacher must know and speak observing correct intonation and stress pattern and this was the most important thing that a teacher must have.

In the case of stress on the result, there are sequence of result of the research, they are average score for first syllable and second syllable 
and low score for 2 stresses in a word. It seems like the student did not really pay attention to pronunciation. They did not understand on how to place stress properly. The understanding on how to place stress can be affected by their background knowledge about the stress. It means the students still need more knowledge about English word stress and practicing more in order to make a correct pronunciation. It also showed that English lecturers also have more reposnsibility in the process of teaching and learning. Student is habit to hear the corrrect pronunciation of the word maybe is one way to understand about the correct stress of the word.

In this study, there were some previous study which is related to the research title, first, Veronica ( 2017 ) was about the syllable stress placement. In this research, the researcher focused on the knowledge of the students. The data were collected by using test of the isolated word. The result of the research found that the

English students have a low knowledge of word stress. Next Anggi Oktaviani (2017) was about the word stress pattern by the students of English Education University of Bengkulu. The result of the study found there seems to be other patterns of the stress spoken by the subject such as multi stressed (MS) and no stress (NS).

Based on those previous studies, this research confirmed the result of the studies based on Anggi Oktaviani (2017), it showed that the data collecting method did not influence. The student still pronounce the word by using their feeling and without thinking about the rule.

\section{Conclusion and Suggestion}

Based one the result of 19 students that have highest GPA or Speaking and Phonetic Phonology grades or both of them from each class at English Department Study Program at University of Bengkulu, the researcher found the that most of the subjects of the research got average predicate when they pronounced a word with first syllable stress and second syllable stress; and low predicate for 2 stresses in a word. This research also confirms the previous study by Veronica (2017) that the 
students were in low predicate in pronouncing words so the result is still consistent eventhough using different method.

\section{Suggestion}

Considering the conclusion of this research, the researcher would like to propose some suggestion for :1. The students of English Education Study Program, the University of Bengkulu, The students are suggested to improve their pronunciation like by recording and listening it by themselves and keep improving the way for practice and analyze their pronunciation with the modern technology. 2. The Lecture in English Education Study Program, The lectures are suggested to more pay attention to the pronunciation and find effective technique to deal with pronunciation and what they did so far is good but according to the result expected to be even better. 3. The English Education Study Program, The English Education Studey Program is suggested to have a pronunciation practice subject because there is no particular subject dealing with pronunciation. 4. Further Researchers, Further Researchers are suggested to find out the data on real speaking situation, since the data of this research was taken on unreal speaking situation. This is very important in order to know more and confirm about English word stress errors by the English student.

\section{References}

Arikunto, Suharsimi. (2013). Prosedur Penelitian: Suatu Pendekatan Praktik. Edition. XV; Jakarta: Rineka Cipta.

Aggrawal Y.P. (2008). Science of Educational Research. Indian: Nirmal Book Agency.

Bian, F. (2003). The Influence of Chinesse Stress on English Pronunciation Teaching and Learning, English Language Teaching, 199-220. Canada : Canadian Center of Science and Education.

Cruttenden, A. (2008). Gimson's Pronunciation of English. London: Hodder education.

Fudge, E. (2015). English word-stress. New York: Routladge. 
Ladefoged, Peter. (1982). A course in Phonetics, Second Edition. Toronto: Harcourt Brace Jovanovich.

Hornby,A,S. (1974). Cambridge Advance Learner's Dictionary. Oxford University press.

Meidy Yuhar Algifari. (2017). Analyzing Students' Pronunciation of Word Stress of IET 7 Students of Cambridge English College (CEC). Makassar: Makassar.

Pierrel, Jonathan J. (2010). "Developing Materials for Teaching Word Stress in English" "A Research Paper Submitted to the Graduate School in Partial Fulfillment of Requirements for the Degree Masters of Arts. Muncie Indiana: Ball State University.

Sabarudin, S. And Kurniawan ,I. (2016). A Descriptive Analysis of English Stress Pattern of Word by Student of the English Education Study Program, the University of Bengkulu. Syimposium of International Languages and Knowledge, ( pp,217-221)

Toro - Soto, et al ,. (2007), Stress Placement and Word Segmentation by Spanish Speakers, Psycologica: International Journal of Methodology and Experimental Psychology, 28(2), 167 - 176.

Veronica, S. (2017). An Analys on English Syllable Stress Placement of the English Study Programs Students. Bengkulu: University of Bengkulu

\section{Writer Information}

\begin{tabular}{|l|l|}
\hline Name & Ronaldi Styvant \\
\hline Affiliation & $\begin{array}{l}\text { English Education Study Program, Department of } \\
\text { Language and Art, University of Bengkulu }\end{array}$ \\
\hline Email & ronaldystyvant@gmail.com \\
\hline Phone Number & +6282281932279 \\
\hline
\end{tabular}

